УДК 821.163.41-1(=113.4)

https://doi.org/10.18485/msc50.2019.1.ch9

Пер Јакобсен

\title{
ДАНСКИ ПРЕВОДИ ВУКОВИХ ПЕСАМА
}

Крајем прошлога и почетком овога века добили смо у Данској један низ радова о фолклористици па и преводе народне поезије других народа. Ове публикације су биле једна врста продужења или проширења рада на сакупљању поезије и епике данског народа. Тај рад има у Данској дугачку традицију и дубоке корене - имамо збирке народних песама чак из 16. и 17. века, већим делом скупљене од племићких дама. У доба романтике скупљачки рад народне књижевности доживео је као и у другим земљама велики успон. Од разоноде племићких дама претворио се у озбиљан рад учених људи и научника.

Објављивање народне књижевности других народа био је одраз интересовања за егзотичност туђинског света, које је владало око 1900. године. У области наше сопствене фолклористике тако рећи није више било шта да се забележи; марљиви скупљачки рад романтике се приближавао крају, али зато су људи који су познавали стране језике и културе отварали један сасвим нов свет лепоте и свежине својим преводима народне књижевности других народа. Тако је објављено доста чланака и превода, као на пример преводи румунске и француске народне поезије познатог романиста Kristoffera Nyropa. Чувени лингвист Холгер Педерсен је такође радио на том пољу, мада његове албанске народне приче, штампане 1895. год. нису биле приступачне за већу читалачку публику - штампане су наиме на албанском језику и имале су свакако пре свега лингвистичке сврхе. Поред једног чланка о српској народној поезији професора Smitha, објављена је једна мала збирка српских лирских и једно 5-6 епских песама у преводу Thora Lange-a, збирка која није - и поред успелог превода - могла с обзиром на њен обим да буде репрезентативна. Даље је писац Carl Andersen под насловом „Гусле” препевао неколико српских песама по Франкеловом немачком издању; али тај Франкелов превод може само да се сматра као допуна ранијих немачких превода па не садржи скоро ниједну од важнијих и монументалнијих песама. 
Прва и досада једина повећа и репрезентативнија збирка српске народне поезије је дело једног поштанског службеника у једном данском провинцијском граду. Звао се Јохан Грове и имао је, када је објавио своју књигу, већ низ књига и превода иза себе. Бавио се између осталог јапанским фолклором и пољском књижевношћу.

На жалост овај учени и талентовани човек није знао српски па је морао да се служи немачким преводима Therese Auguste Louise von Jakob, која је од почетних слова свог имена саставила мало чудни псеудоним Talvj даље преводима W. Gerharda, Siegfrieda Kappera, Adolfa Strausza, Goetze-a Friedericha Krausza и Karla Müllera.

Иако Гровов превод дакле није био са оригиналног језика, мора се рећи да је веома успео, и то важи и за форму и за садржину. Песме су препеване у десетерцима а сачуване су одлике и карактеристике јуначких песама.

Да бих дао малу представу о односу превода према српском оригиналу навешћу један одломак данског текста, прозни превод са данског и исти одломак како га је Вук забележио. Ради се о почетку познате песме „Зидање Скадра”:

1 Borg blev bygget af tre gjaeve brodre, $\quad-\cup-\cup \mid-\cup-\cup-\cup$

2 Bygget af de tre Merljavtschevitscher,

3 Og kong Vukaschin var aeldste broder,

4 Vojvod Ugljescha kom naest i alder,

5 Men den yngste af de tre var Gojko.

$6 \mathrm{Nu}$ i trende ar de havde bygget

7 Ved Bojana's bred pa borgen Skadar.

8 Dem tilhande gik trehundred Mestre;

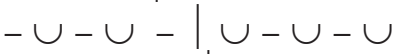

$\cup \cup-\cup \cup \mid \cup-\cup-\cup$

$-\cup-\cup \cup \mid \cup-\cup-\cup$

$\cup \cup-\cup \mid \cup \cup-\cup-\cup$

$-\cup-\cup-\mid \cup-\cup-\cup$

$\cup-\cup-\mid \cup-\cup-\cup$

$-\cup-\cup \mid-\cup-\cup-\cup$

9 Men de fik ned ej dens grundmur faerdig $-\cup-\cup-\mid \cup-\cup-\cup$

10 Endnu mindre selve borgens mure: -

11 Alt, hvad mestrene om dagen bygged,

12 Rev den onde Vila ned om natten. $-\cup-\cup \mid-\cup-\cup-\cup$

$-\mid \cup-\cup-\cup-\cup-\cup$

$-\cup-\cup-\cup-\mid \cup-\cup$

Превод у прози са данског:

1 Град је зидан од три храбра брата

2 Зидан од три Мрљавчевића

3 И краљ Вукашин је био најстарији брат

4 Војвода Угљеша је био иза њега по старости

5 А најмлађи од њих тројице је био Гојко.

6 Сад три године зидаху

7 На обали Бојане град Скадар

8 Било им је при руци триста мајстора 
9 Али нису ни успели да заврше град

10 Акамоли зидине самог града

11 Све што су мајстори преко дана зидали

12 Зла вила је рушила преко ноћи.

Наслов књиге је „Српске и бугарске народне песме” а књига је штампана 1910. год. у Копенхагену. Састоји се од свега 43 песме. У једном додатку на крају књиге се налази неколико српских народних пословица из Капетановићеве збирке као и мали поговор преводиоца о побратимству код Срба.

Од споменуте 43 песме, 31 су српске а осталих 12 су бугарске. Књига је подељена на 4 дела под насловима:

1. Битка на Косовском Пољу

2. Краљевић Марко

3. унаци и хајдуци

4. Легенде и митови.

Од српских песама, 10 су из косовског циклуса: 4 од њих су песме које се код Вука налазе под насловом „Комади од различнијех косовскијех пјесама" даље налазимо Пропаст Царства Српскога, Цар Лазар и Царииза Милица, Царица Милица и Владета Војвода, Косовка дјевојка, Смрт Мајке Југовића и Обретеније главе Кнеза Лазара.

Већи део песама о Краљевићу Марку су у данској збирци бугарске, али налазимо из Вукових песама песму Марко Кратьевић познаје Очину Сабльу.

Под насловом Јунаци и Хајдуци налазимо међу осталима: Диоба Јакшића, Секула се у змију претворио, Новак и Радивоје продају Грујииу и Грујица и Арапин.

На крају књиге су легенде и митови. На пример Свети Никола, Браћа и сестра и као последња у књизи ваљда најлепша српска епска песма Зидағе Скадра.

У предговору књиге Грове говори о Вуку. Он каже:

Први, који је на пољу народних песама учинио стваран и епохалан скупљачки рад био је човек, који је српски народни језик узвисио до књижевног језика. Тај човек је био Вук Стеф. Караџић. Под тешким материјалним условима и са великим личним жртвама Вук је чинио своје животно дело, које Јужни Словени с правом цене толико да га стално називају „отац Вук”.

О самим српским песмама Грове каже:

Ове народне песме показују изненађујућу разноврсност. Час су плодови маште која је очигледно у блиској сродности са маштом бајки исто- 
чњачког света, час се одликују оштрим смислом за сликовите детаље живота, час изненађују дирљивим карактером описаног конфликта и љупкошћу и финоћом идеје. Грове упоређује садржину неких српских народних песама са нашим данским народним песмама и са заједничким европским митским благом уопште.

Захваљујући Грову и Вук је био присутан у данском културном животу ако не баш друге половине деветнаестог века онда прве деценије двадесетог. Гровова књига била је по изгледу скромна - а тираж није био велики - Али њен значај је у томе што је наш први сусрет са српском књижевношћу.

Случајно, али и симболично, Вук је био посредник тог сусрета.

Када се човек бави неким предметом, један важан задатак му је да нађе и да дефинише границе свог предмета. Бавећи се Вуковим утицајем требало би да испитујемо и границе тог утицаја.

Слушајући јучерашња излагања, и ту мислим нарочито на занимљиво и ангажовано излагање професора Јакубјеца ја, на основу онога што сам данас рекао, видим обрис једне границе код Балтичког Мора. 